\title{
Energy and Exergy Efficiency of Double Slope Passive Solar Still
}

\author{
Jandri Fan HT Saragi ${ }^{*}$, Wawan Septiawan Damanik ${ }^{2}$ \\ ${ }^{1}$ Department of Mechanical Engineering, Faculty of Engineering, Universitas HKBP Nommensen \\ Pematangsiantar, Pematangsiantar, Indonesia \\ ${ }^{2}$ Department of Mechanical Engineering, Faculty of Engineering, Universitas Muhammadiyah Sumatera \\ Utara, Medan, Indonesia \\ *Corresponding author: jandrifan@gmail.com
}

\begin{abstract}
Solar desalination functions to filter water, both sea water and brackish water, to produce clean water that is fit for consumption with energy from the sun. Solar energy is a renewable energy source that has been widely studied for its use. One of its uses is in a double slope passive solar still where the sun is the main source. Energy and exergy obtained from solar energy are not all used to evaporate water in the desalination system, so it is necessary to calculate efficiency energy and exergy in the system. This study aims to obtain data on the amount of efficiency energy and exergy from the double slope passive solar still as well as the factors that affect efficiency energy and exergy. The results showed that energy efficiency was in the range of $30.20 \%$ to $55.15 \%$ and exergy efficiency was in the range of $0.93 \%$ to $5.36 \%$. The factors that influence the amount of energy efficiency and exergy are solar intensity, basin area, basin cover area, amount of water produced and ambient temperature.
\end{abstract}

Copyright (C) 2020. Journal of Mechanical Engineering Science and Technology.

All rights reserved.

Keywords: Desalination, double slope solar still, energy efficiency, exergy efficiency, passive solar still

\section{Introduction}

Water is the most important component in life on earth. All living things need water as a source of life, especially for drinking. For humans themselves, the existence of water to fulfill their daily needs is very important. The need for clean water in Indonesia is increasing every year. The average water requirement for each human being is 125 to 150 liters per day to meet needs, such as washing, cooking, bathing, and others [1].

Recently, the problem that is often experienced is the lack of availability of clean water for consumption or daily needs, especially if it has entered the dry season, many areas lack clean water sources, including state-owned water companies that are no longer able to meet the clean water needs of their people. When the dry season arrives, the availability of clean water is very limited, on the other hand, the high intensity of the sun results in an increase in water consumption for drinking. Some well owners with large amounts of water take advantage of this opportunity to make a profit by selling water to the community. For people who cannot afford water, they only rely on cloudy river water for household needs.

One of the renewable energy sources is solar energy. Solar energy is the largest source found on earth even in the solar system. The use of solar energy as renewable energy can reach 57\% [2]. Currently the use of solar energy in technology is growing rapidly. Many 
companies engaged in technology use solar energy as their energy source, including automotive manufacturers, power plants and electronic equipment. One of the uses of solar energy as an energy source to produce clean water is the desalination system [3]. The basic principle of desalination is to evaporate water into condensate. One of the factors that causes water to evaporate is by providing heat energy [4][5]. The advantage of the water desalination used is that it is able to produce clean water that can be used to meet daily water needs such as drinking, cooking, washing and so on. In addition, this desalination tool is easy to maintain and can be used in areas that lack clean water with high solar intensity.

The thermal energy used to evaporate water comes from solar energy through radiant heat transfer. In the desalination process, not all of the thermal energy obtained from the sun is used to evaporate water into condensate. This is what makes it necessary to know how much energy efficiency can be used to evaporate water. The greater the efficiency of energy use, the greater the amount of water produced by the desalination system [6].

The quality of the energy used to evaporate water into condensate water is called exergy. Exergy in a double slope passive solar still shows the amount of energy used to evaporate water which is also influenced by the ambient temperature so that the system is in equilibrium with its environment. The value of exergy greatly affects the evaporation and condensation processes. Exergy efficiency shows the amount of energy that can be converted into work/effort to evaporate water into condensate water from the total solar exergy that occurs in the system [7].

The amount of efficiency energy and exergy in solar desalination devices has been studied before, including research conducted by Chandrashekara and Yadav which obtained an internal energy efficiency of 57.1\% [8], a study conducted by Tiwari and Sahota, showed that energy efficiency and exergy efficiency varied between 5.4-54.8\% and 0.4-10.7\% [9], research conducted by Yari, Mazareh, and Mehr with the magnitude of energy efficiency and daily exergy efficiency of $6.86 \%$ and $16.65 \%$ [10] and research conducted by Sahota and Tiwari with $37.78 \%$ energy efficiency and $4.92 \%$ exergy efficiency [11][12]. The research conducted has differences with previous studies where the ambient temperature and solar intensity are different. Previous research was conducted in India with a higher ambient temperature and daytime solar intensity than in Indonesia.

\section{Material and Methods}

The research method used was experimental. The design double slope solar still for experiment is shown in Figure 1 and and Figure 2. The basin in the desalination device is made of aluminum composite panel with a thickness of $3 \mathrm{~mm}$. The basin is coated with Styrofoam and the outside is coated with aluminum foil which prevents heat from escaping from the basin. The basin cover is made of clear glass material with a thickness of $3 \mathrm{~mm}$ with a size of $1 \times 1 \mathrm{~m}$. The basin is $2000 \mathrm{~mm}$ long and $1000 \mathrm{~mm}$ wide. At the bottom of the basin a thermocouple is placed to measure the temperature of the water and on the wall of the basin a thermocouple is placed to measure the temperature of the water vapor. On the glass part, 2 thermocouples are placed on the outside and inside so that the thermocouple used in this study is 6 . The slope angle of the basin which is covered by glass is $15^{\circ}$ at the top so that the water is condensate. In Table 1, the dimensions, sizes and symbols used are presented.

The basin position is placed towards sunrise and sunset in order to obtain maximum solar intensity. The basin functions as an evaporator where in the basin there is an increase 
in temperature caused by the basin cover made of clear glass. A thermocouple is installed on the inner side of the basin lid or the direction of the sunrise, which measures the temperature of the cover, and two thermocouples are installed on the basin lid that is facing west or the direction of the sun. In addition to thermocouples, other measuring instruments used are the solar intensity sensor and wind speed sensor, each of which is placed beside the basin. Data collection time was recorded every 1 hour with data output in MS form. Excel.

Table 1. Dimensions, sizes, and symbols

\begin{tabular}{llll}
\hline Symbol & Value & Symbol & Value \\
\hline $\mathrm{A}_{\mathrm{b}}$ & $1,932 \mathrm{~m} \times 1 \mathrm{~m}$ & $\alpha_{\mathrm{g}}$ & 0,05 \\
$\mathrm{Kg}$ & $0,78\left(\mathrm{~W} / \mathrm{m}^{\circ} \mathrm{C}\right)$ & $\alpha_{\mathrm{b}}$ & 0,8 \\
$\mathrm{Lg}$ & $0,003 \mathrm{~m}$ & $\alpha_{\mathrm{w}}$ & 0,6 \\
$\mathrm{Ki}$ & $0,039\left(\mathrm{~W} / \mathrm{m}^{\circ} \mathrm{C}\right)$ & $\epsilon_{\mathrm{w}}$ & 0,95 \\
$\mathrm{Li}$ & $0,02 \mathrm{~m}$ & $\epsilon_{\mathrm{g}}$ & 0,95 \\
$\theta$ & $15^{\circ}$ & $\sigma$ & $5,67 \times 10^{-8}\left(\mathrm{~W} / \mathrm{m}^{2} \mathrm{~K}^{4}\right)$ \\
$\mathrm{x}$ & 0,2595 & $\mathrm{~A}_{\mathrm{gE}}$ & $1 \mathrm{~m} \times 1 \mathrm{~m}$ \\
$\mathrm{Mw}$ & $38,640 \mathrm{Kg}$ & $\mathrm{AgW}_{\mathrm{gW}}$ & $1 \mathrm{~m} \times 1 \mathrm{~m}$ \\
\hline
\end{tabular}

$1,2,3,4,5$, and 6 is Thermocouple Sun

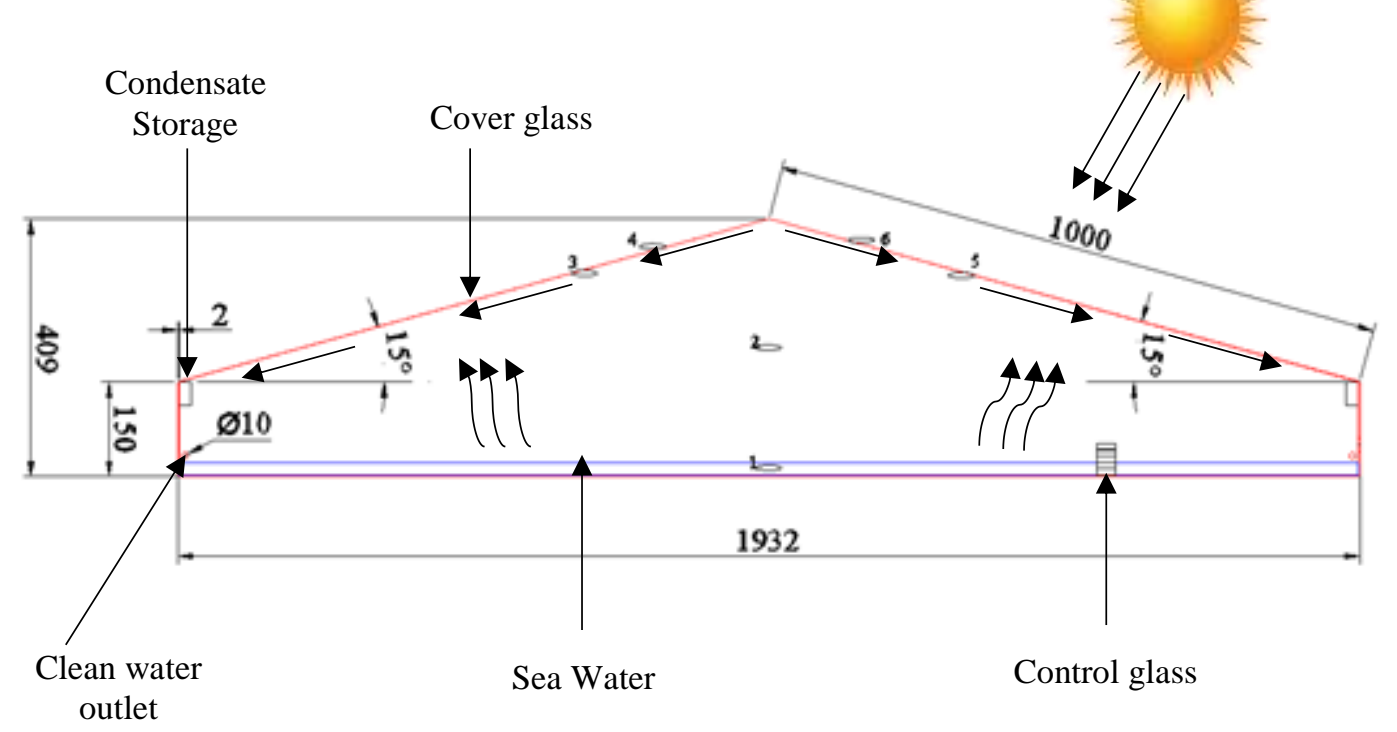

Fig. 1. Design double slope solar still

Data collection was carried out from $08.00 \mathrm{am}$ to $06.00 \mathrm{pm}$. At the beginning of data collection, water is entered into the basin until it reaches a height of $0.02 \mathrm{~m}$ by looking at the control glass on the side of the basin, then begins to record the initial temperature of the water, basin cover, ambient temperature, wind speed, solar intensity and temperature in the basin. . Beside the basin there is a reservoir that holds seawater and is used when the water in the basin decreases by opening the shutoff tap. The bottom side of the glass has a groove that is made as a place for condensate water to escape to the reservoir under the basin. The water in the basin will get heat from the sun through the surface of the cover glass which is 
made to the west and east to get the maximum solar intensity. When the water temperature increases, the water will evaporate. The temperature of the glass will be cooler than the temperature of the water due to the convection heat transfer between the surface of the cover glass and the surrounding air. Moisture condenses and condensate water will stick to the inner surface of the cover glass. Because the angle of the glass surface to the basin is made $15^{\circ}$ so that the water will flow into the channel where the water comes out to the water reservoir which is below the basin.

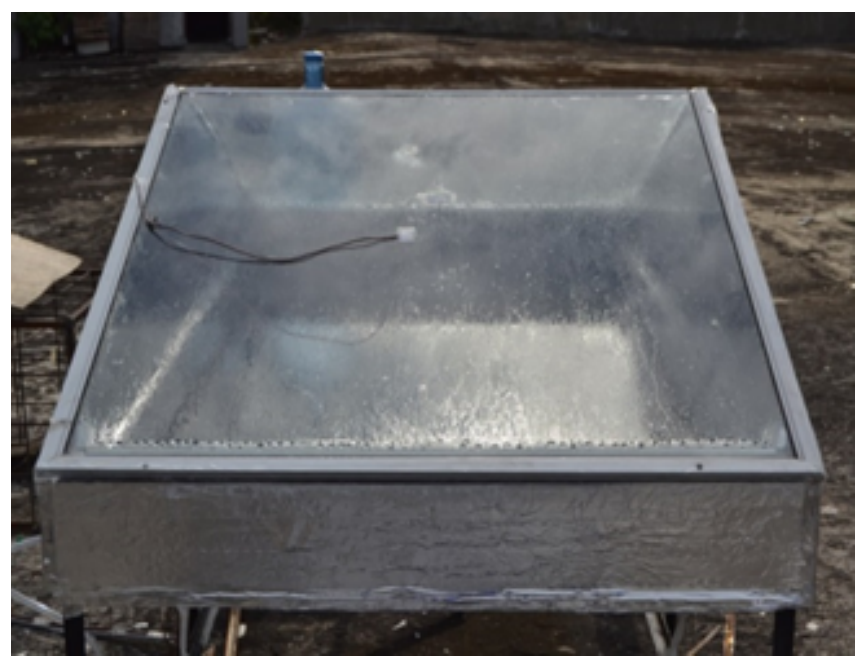

Fig. 2. Double slope solar still

\subsection{Heat Transfer Coefficient}

The calculated heat transfer coefficient is radiation heat transfer coefficient, convection heat transfer coefficient and evaporative heat transfer coefficient are stated as follows:

\section{1) Radiation heat transfer coefficient}

Radiation heat transfer coefficient can be calculated using the formula [9][12]:

$$
h_{r w g}=\varepsilon_{e f f} \sigma\left[\left(T_{w}+273\right)^{2}+\left(T_{g i}+273\right)^{2}\right]\left(T_{w}+T_{g i}+546\right)
$$

\section{2) Convection heat transfer coefficient}

Convection heat transfer coefficient is calculated as follows [9][12]:

$$
h_{c w g}=0.884\left[\left(T_{w}-T_{g i}\right)+\frac{\left(P_{w}-P_{g i}\right)\left(T_{w}+273\right)}{2.689 \times 10^{5}-P_{w}}\right]^{1 / 3}
$$

Where,

$$
\begin{aligned}
& P_{w}=\exp \left[25.317-\left(\frac{5144}{273+T_{w}}\right)\right] \\
& P_{g i}=\exp \left[25.317-\left(\frac{5144}{273+T_{g i}}\right)\right]
\end{aligned}
$$




\section{3) Evaporation coefficient}

Evaporation coefficient is calculated by the following formula [9][12]:

$$
h_{\text {ewg }}=0.016273 h_{c w g}\left(\frac{P_{w}-P_{g i}}{T_{w}-T_{g i}}\right)
$$

4) Desalination water

Desalinated water can be calculated as follows [9][13][14]:

$$
\dot{M}_{\text {ew }}=\frac{h_{\text {ewg }}\left(T_{w}-T_{g i}\right) 3600}{L}
$$

Where,

$$
\begin{aligned}
& L=3.1615 \times 10^{6}+\left[1-\left(7.6166 \times 10^{-4} T_{v}\right)\right]_{f o r T_{v}>70^{\circ} \mathrm{C}} \\
& L=2.4935 \times 10^{6}+\left[1-\left(\begin{array}{l}
9.4779 \times 10^{-4}\left(T_{v}\right)+1.3132 \times 10^{-7}\left(T_{v}^{2}\right)- \\
4.7974 \times 10^{-9}\left(T_{v}^{3}\right)
\end{array}\right)\right]_{f o r T_{v}<70^{\circ} \mathrm{C}}
\end{aligned}
$$

\subsection{Energy and Efficiency Energy}

Hourly of system energy used to obtain distilled water is given as follows [9][11][15]:

$$
E_{\text {Hourly }, \text { En }}=\left\lfloor h_{\text {ewgE }}\left(T_{w}-T_{\text {giE }}\right)+h_{\text {ewgW }}\left(T_{w}-T_{g i W}\right)\right\rfloor A_{b}
$$

and the thermal efficiency per hour can be expressed as follows [9][11][16][17]:

$$
\eta_{t h}=\frac{\left[\dot{M}_{e w E}+\dot{M}_{e w W}\right] \times L}{\left[A_{g E} I_{S E}(t)+A_{g W} I_{S W}(t)\right] \times 3600} \times 100 \%
$$

\subsection{Exergy and Efficiency Exergy}

Exergy value can be obtained by the concept of entropy which is derived from the second law of thermodynamics. Exergy efficiency is the ratio of exergy output to exergy input, and is stated as follows [9][14] [18]:

$$
\begin{aligned}
& \eta_{E x}=\frac{E_{\text {xoutput }}}{E_{\text {xinput }}} \\
& E_{\text {xinput }}=E_{\text {x sun }}=\left[\left(A_{g E} I_{S E}(t)\right)+\left(A_{g W} I_{S W}(t)\right)\right]\left[1-\frac{4}{3}\left(\frac{T_{a}}{T_{s}}\right)+\frac{1}{3}\left(\frac{T_{a}}{T_{s}}\right)^{4}\right]
\end{aligned}
$$

Where Ts is the sun's temperature $6000 \mathrm{~K}$, whereas for exergy output can be written as follows[9][11][14][15]:

$$
E_{\text {xoutput }}=E_{\text {xevap }}=h_{\text {ewg }} \frac{A_{b}}{2}\left[\left(T_{w}-T_{g i}\right)-\left(T_{a}+273\right) \ln \left(\frac{T_{w}+273}{T_{g i}+273}\right)\right]
$$




\section{Results and Discussions}

Energy and exergy in the desalination system comes from solar energy. Figure 3 shows a graph of the amount of energy and energy efficiency produced in a double slope passive solar still. In the Figure 3, it can be seen that the increase and decrease in energy and energy efficiency are directly proportional. On the second day, the energy efficiency used to evaporate water in the system was $30.20 \%$ of the total energy produced, which was around $1.23 \mathrm{kWh}$. In this case, there is about $2.84 \mathrm{kWh}$ of energy not used to get clean water. This is because the testing time is only carried out until $06.00 \mathrm{pm}$ so that data is no longer recorded after that time. On the fourth day, the total energy generated in the system was $18.89 \mathrm{kWh}$, amounting to $47.85 \%$ or only $9.04 \mathrm{kWh}$ of energy used to evaporate water. The fifth day is a day where the efficiency of thermal energy used is very high, namely $55.15 \%$ of the total energy produced of $16.65 \mathrm{kWh}$.

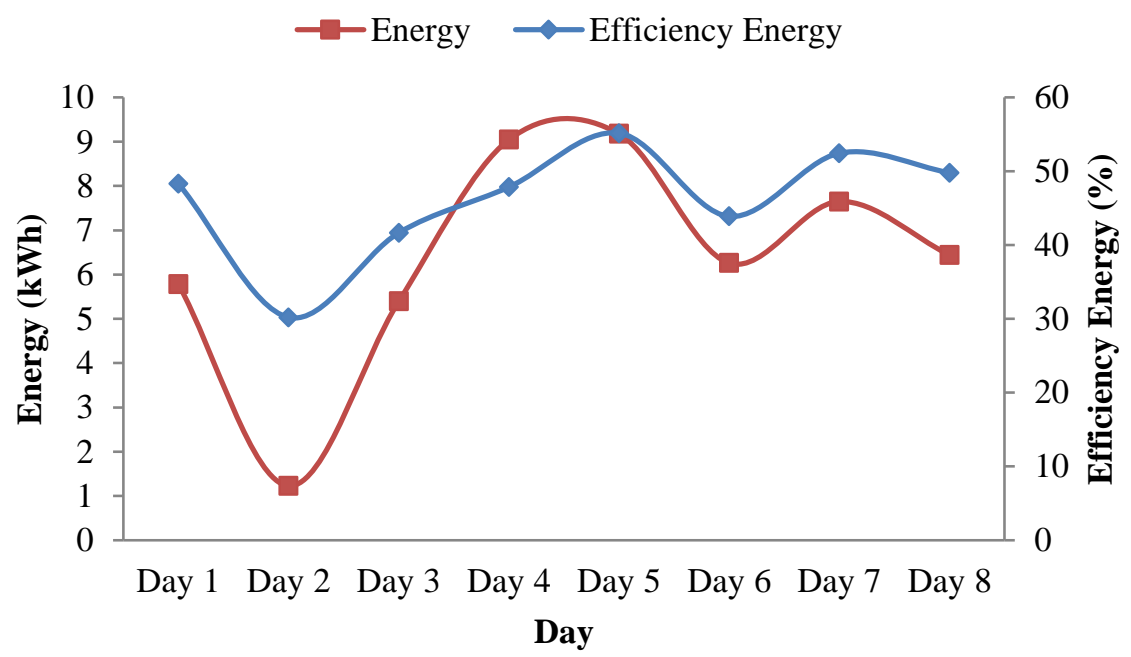

Fig. 3. Graph of energy and efficiency energy

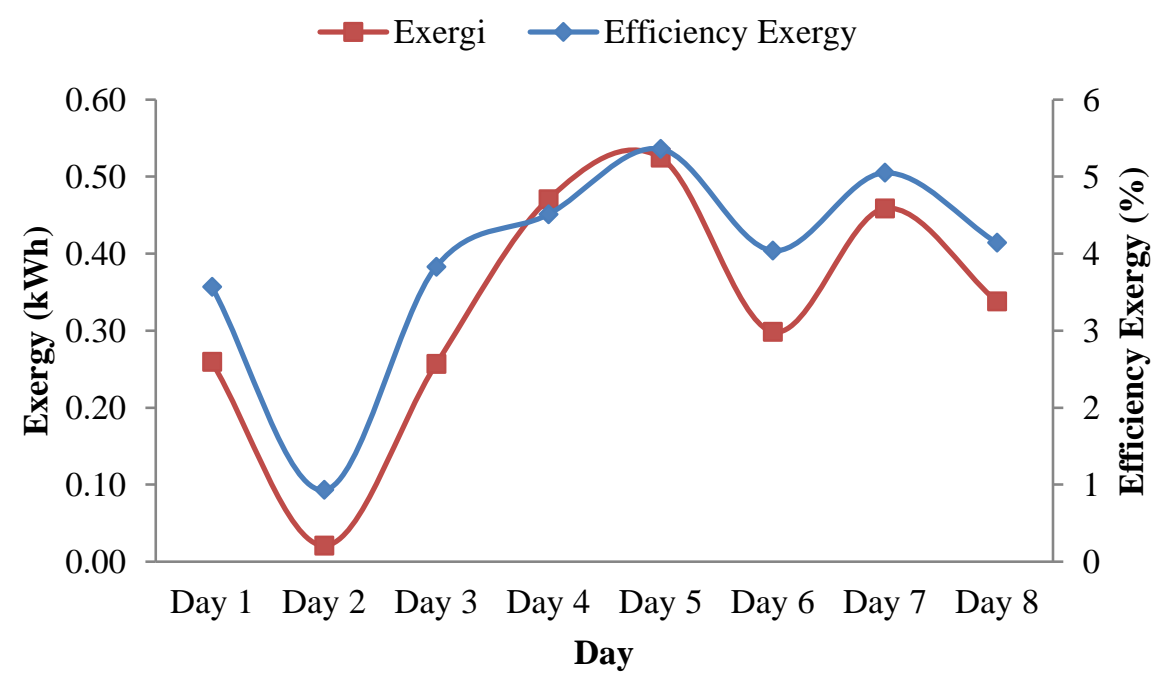

Fig. 4. Graph of exergy and efficiency exergy 
Figure 4 shows a graph of the exergy and exergy efficiency of a double slope passive solar still. From the data obtained, it was found that the exergy value and the lowest exergy efficiency occurred on the second day. The exergy efficiency on the second day was $0.93 \%$. The magnitude of this exergy efficiency indicates that the energy that can be converted into work / business is $0.02 \mathrm{kWh}$ or $0.93 \%$ of the total solar exergy that occurs in the system during the test time, which is $2.01 \mathrm{kWh}$. The low energy, exergy, energy efficiency and exergy efficiency on the second day are caused by the low solar intensity at that time so that the energy and exergy in the system is smaller than the other test days. The exergy efficiency on the fifth day was the largest exergy efficiency at the time of testing, which was $5.36 \%$. The magnitude of this exergy efficiency shows that the energy that can be converted into work / business is $0.52 \mathrm{kWh}$ or $5.36 \%$ of the total solar exergy that occurs in the system during the test time, which is $9.70 \mathrm{kWh}$.

The thermal energy contained in a double slope passive solar still is influenced by the radiation heat transfer coefficient, convection, evaporation and the amount of condensate water produced during the process. Meanwhile, energy efficiency is strongly influenced by the solar intensity, the cross-sectional area of the basin cover and the amount of condensate water produced. The magnitude of the exergy value is highly dependent on the ambient temperature and the solar intensity and the magnitude of the exergy efficiency value is strongly influenced by the area of the basin cover, the solar intensity, the evaporation heat transfer coefficient, the water temperature in the basin, and the ambient temperature. To increase the efficiency value, what needs to be done is to reduce the surface area of the glass or add coolant to the glass surface so that the amount of water produced is greater and the efficiency will be even greater.

\section{Conclusions}

The data from the test results show that the amount of energy and energy efficiency occurring on the second day is the lowest energy and energy efficiency during the test with an energy magnitude of $1.23 \mathrm{kWh}$ and an efficiency of $30.20 \%$. On the fourth day, the energy produced was the largest at $18.89 \mathrm{kWh}$, while the largest energy efficiency was on the fifth day with an efficiency of $55.15 \%$. The largest exergy in the system occurred on the fifth day with a magnitude of $0.52 \mathrm{kWh}$ with an exergy efficiency of $5.36 \%$ and the lowest occurred on the second day with a magnitude of $2.01 \mathrm{kWh}$ with an exergy efficiency of $0.93 \%$. The factors that affect the value of energy and energy efficiency as well as exergy and exergy efficiency in a double slope passive solar still are solar intensity, basin area, basin cover area, amount of water produced and ambient temperature.

\section{Nomenclature}

$\mathrm{A}_{\mathrm{b}} \quad=$ basin area of solar still $\left(\mathrm{m}^{2}\right)$

$\mathrm{A}_{\mathrm{gE}}=$ surface areaof condensingcover of east side of solar still $\left(\mathrm{m}^{2}\right)$

$\mathrm{A}_{\mathrm{gW}}=$ surface area of condensing cover of west side of solar still $\left(\mathrm{m}^{2}\right)$

$\mathrm{h}_{\mathrm{cwg}}=$ convective heat transfer coefficient from water to glass surface $\left(\mathrm{W} / \mathrm{m}^{2}{ }^{\circ} \mathrm{C}\right)$

$\mathrm{h}_{\text {ewgE }}=$ evaporative heat transfer coefficient from basefluid to east side glass cover $\left(\mathrm{W} / \mathrm{m}^{2}\right.$ $\left.{ }^{\circ} \mathrm{C}\right)$

$\mathrm{h}_{\mathrm{ewgW}}=$ evaporative heat transfer coefficient from basefluid to west side glass cover $\left(\mathrm{W} / \mathrm{m}^{2}{ }^{\circ} \mathrm{C}\right)$

$\mathrm{h}_{\mathrm{rwg}}=$ radiative heat transfer coefficient from water to glass surface $\left(\mathrm{W} / \mathrm{m}^{2}{ }^{\circ} \mathrm{C}\right)$

$I(t)=$ solar intensity $\left(\mathrm{W} / \mathrm{m}^{2}\right)$ 
$\mathrm{I}_{\mathrm{SE}}=$ solar intensity on east side of condensing cover $\left(\mathrm{W} / \mathrm{m}^{2}\right)$

$\mathrm{I}_{\mathrm{SW}}=$ solar intensity on west side of condensing cover $\left(\mathrm{W} / \mathrm{m}^{2}\right)$

$\mathrm{L} \quad=$ latent heat of vaporization $(\mathrm{J} / \mathrm{kg})$

$\dot{\mathrm{M}}_{\text {ewE }}=$ the results obtained from the eastern system $(\mathrm{Kg})$

$\dot{\mathrm{M}}_{\mathrm{ewW}}=$ the results obtained from the western system $(\mathrm{Kg})$

$\mathrm{P}_{\mathrm{gi}} \quad=$ partial pressure at glass $\left(\mathrm{N} / \mathrm{m}^{2}\right)$

$\mathrm{P}_{\mathrm{w}} \quad=$ partial vapor pressure at water surface $\left(\mathrm{N} / \mathrm{m}^{2}\right)$

$\mathrm{T}_{\mathrm{a}}=$ ambient temperature $\left({ }^{\circ} \mathrm{C}\right)$

$\mathrm{T}_{\text {giE }}=$ temperature of inner surface of the east side glass cover $\left({ }^{\circ} \mathrm{C}\right)$

$\mathrm{T}_{\text {giW }}=$ temperature of inner surface of the west side glass cover $\left({ }^{\circ} \mathrm{C}\right)$

$\mathrm{T}_{\text {gi }}=$ temperature of inner surface $\left({ }^{\circ} \mathrm{C}\right)$

$\mathrm{T}_{\mathrm{v}} \quad=$ vapor temperature $\left({ }^{\circ} \mathrm{C}\right)$

$\mathrm{T}_{\mathrm{w}}=$ basefluid temperature $\left({ }^{\circ} \mathrm{C}\right)$

$\mathrm{T}_{\mathrm{s}} \quad=$ Sun temperature $\left({ }^{\circ} \mathrm{C}\right)$

$\sigma \quad=$ Stephan-Boltzman coefficient $\left(\mathrm{W} / \mathrm{m}^{2} \mathrm{~K}^{4}\right)$

$\varepsilon_{\text {eff }}=$ effective emissivity

$\eta_{\mathrm{th}}=$ Thermal Efficiency $(\%)$

\section{References}

[1] Saragi, J. H. T., Napitupulu, F. H., Nasution, A. H., and Ambarita, H., "Exergy analysis of double slope passive solar still," IOP Conf. Ser. Mater. Sci. Eng., vol. 725(1), 2020.

[2] Eltawil, M. A., Zhengming, Z., and Yuan, L., "A review of renewable energy technologies integrated with desalination systems," Renew. Sustain. Energy Rev., vol. 13(9), pp. 2245-2262, 2009.

[3] Sahota L., and Tiwari, G. N., "Exergoeconomic and enviroeconomic analyses of hybrid double slope solar still loaded with nanofluids," Energy Convers. Manag., vol. 148, pp. 413-430, 2017.

[4] Qiblawey H. M., and Banat, F., "Solar thermal desalination technologies," Desalination, vol. 220(1-3), pp. 633-644, 2008.

[5] Damanik, W. S., Napitupulu, F. H., Nasution, A. H., and Ambarita, H., "Energy analysis of double slope aktive solar still," IOP Conf. Ser. Mater. Sci. Eng., vol. 725(1), 2020.

[6] Dwivedi, V. K., and Tiwari, G. N., "Experimental validation of thermal model of a double slope active solar still under natural circulation mode," Desalination, vol. 250(1), pp. 49-55, 2010.

[7] Ranjan, K. R., Kaushik, S. C., and Panwar, N. L., "Energy and exergy analysis of passive solar distillation systems," Int. J. Low-Carbon Technol., vol. 11(2), pp. 211221, 2016.

[8] Chandrashekara, M., and Yadav, A., "Water desalination system using solar heat: A review,” Renew. Sustain. Energy Rev., vol. 67, pp. 1308-1330, 2017.

[9] Tiwari, G. N., and Sahota, L., "Review on the energy and economic efficiencies of passive and active solar distillation systems," Desalination, vol. 401, pp. 151-179, 2017. 
[10] Yari, M., Mazareh, A. E., and Mehr, A. S., "A novel cogeneration system for sustainable water and power production by integration of a solar still and PV module," Desalination, vol. 398, pp. 1-11, 2016.

[11] Sahota L., and Tiwari, G. N., "Effect of nanofluids on the performance of passive double slope solar still: A comparative study using characteristic curve," Desalination, vol. 388, pp. 9-21, 2016.

[12] Sahota L., and Tiwari, G. N., "Effect of A12O3 nanoparticles on the performance of passive double slope solar still," Sol. Energy, vol. 130, pp. 260-272, 2016.

[13] Dwivedi V. K., and Tiwari, G. N., "Comparison of internal heat transfer coefficients in passive solar stills by different thermal models: An experimental validation," Desalination, vol. 246(1-3), pp. 304-318, 2009.

[14] Singh, D. B., Tiwari, G. N., Al-Helal, I. M., Dwivedi, V. K., and Yadav, J. K., "Effect of energy matrices on life cycle cost analysis of passive solar stills," Sol. Energy, vol. 134, pp. 9-22, 2016.

[15] Sahota, L., Shyam, and Tiwari, G. N., "Energy matrices, enviroeconomic and exergoeconomic analysis of passive double slope solar still with water based nanofluids," Desalination, vol. 409, pp. 66-79, 2017.

[16] Singh, R. V., Dev, R., Hasan, M. M., and Tiwari, G. N., "Comparative Energy and Exergy Analysis of Various Passive Solar Distillation Systems," Proc. World Renew. Energy Congr. - Sweden, 8-13 May, 2011, Linköping, Sweden, vol. 57, pp. 39293936, 2011.

[17] Dwivedi V. K., and Tiwari, G. N., "Annual Energy and Exergy Analysis of Single and Double Slope Passive Solar Stills," Trends in Applied Sciences Research, vol. 3. pp. 225-241, 2008.

[18] Rahbar, N., Gharaiian, A., and Rashidi, S., "Exergy and economic analysis for a double slope solar still equipped by thermoelectric heating modules - an experimental investigation,” Desalination, vol. 420, pp. 106-113, May 2017. 